\title{
STATUS OF THE RESOURCE ROOM MODEL IN LOCAL EDUCATION AGENCIES: A DESCRIPTIVE STUDY
}

\author{
Gaye McNutt and Marilyn Friend
}

\begin{abstract}
Although resource room programs are widely used, only limited information is available on implementation of this model. The purpose of the present investigation was to survey a nationwide sample of local education agencies (LEAs) to determine the status of this model at the local level and to identify the characteristics of resource programs as they are currently implemented. A questionnaire was sent to a $5 \%$ stratified random sample of LEAs with a $53.4 \%$ response rate. Results indicated that most local education agencies use resource room programs, and have done so for at least three years. Most programs are multicategorical. The majority of respondents indicated that they believed the programs were effective, and that they would continue to be used. A major conclusion from this study relates to the need for descriptions of model resource room programs and practices.
\end{abstract}

The resource room is the most popular model for delivery of educational services to the mildly handicapped (Friend \& McNutt, in press; Marsh, Price, \& Smith, 1983; Mercer \& Mercer, 1981; Wiederholt, Hammill, \& Brown, 1983). Yet, remarkably little is known about the implementation of this model. For example, Sindelar and Deno (1978) located only 17 studies on the effectiveness of the resource room; Wiederholt et al. (1983) found 30. While other types of articles are available on resource room programs (e.g., authors' opinions or descriptions of individual resource rooms), this number is surprisingly small considering the widespread use of such programs.

A recent survey of State Departments of Education (Friend \& McNutt, in press) pointed to certain patterns in resource room guidelines. For example, all states and the District of Columbia offer resource rooms as part of their service delivery system. Usually, these programs are categorical or multicategorical in nature. As might be expected, the model is most often used to serve the mildly-to-moderately handicapped.

Results of the same study highlighted the lack of information about certain aspects of the resource room model. Particularly notable was the absence of (a) specifications concerning the services offered through resource room programs, (b) job descriptions for resource teachers, and (c) per-pupil cost of resource room services. This situation may stem from State Departments of Education setting only general parameters, thereby allowing local education agencies (LEAs) to tailor programs to their specific needs. If this is the case, data unavailable at the state level may be obtainable from individual LEAs.

The purpose of this investigation was to survey a nationwide sample of local education agencies regarding the operation of their resource room programs. Such information was sought as a means of determining the general status of this service delivery model at the local

GAYE MC NUTT, Ph.D., works for the Alief Independent School District, Houston.

MARILYN FRIEND, Ph.D., is Assistant Professor, College of Education, University of Oklahoma. 
level, and identifying predominant characteristics of resource room programs as they are currently implemented.

\section{Instrumentation}

\section{METHOD}

A questionnaire was developed to obtain pertinent data about resource room programs. The content of the questionnaire items was based on a literature review of resource room program characteristics as well as the state level survey used in a previous study (Friend \& McNutt, in press). In its final form, the questionnaire contained 20 items divided into two sections. One part requested demographic data while the other focused on the structure and administration of resource room programs. For most items, respondents had to check the appropriate choice; a few questions required a written response.

\section{Respondents and Procedure}

The following procedure was used to identify a 5\% stratified random sample of local education agencies in the United States: The largest LEA for each state was always included (Hawaii and the District of Columbia were excluded because they had been included in the state level survey - both are single-district entities). The remaining slots were allocated among the nine geographic regions of the country in proportion to the total number of students enrolled within each region. The slots allotted to each geographical region were, in turn, distributed among the states in that region based on the number of LEAs within each state. Specific LEAs were identified by choosing each $n$th one based on the particular state's allotment.

The questionnaire was mailed to the Special Education Director in each of the identified LEAs. It was accompanied by a cover letter describing the purposes of the study and outlining the directions for completing the questionnaire. If a reply was not obtained within three months, a follow-up letter and questionnaire were sent.

Responses were received from at least one LEA in every state with an overall response rate of $53.4 \%$. Table 1 contains the number of LEAs in each region that were included in the sample, the percentage of responses from each region, and related information.

Of the 414 respondents, $78.5 \%$ held adminis- trative or supervisory positions; $19.8 \%$ were teachers; and $1.7 \%$ held other positions. The following demographic data were obtained from the participants:

1. Most respondents represented school districts $(89.1 \%)$, while $9.4 \%$ were from cooperatives, and $1.5 \%$ from other administrative units such as supervisory unions.

2. Rural areas accounted for $36.6 \%$ of the sample, followed by small towns, $33.4 \%$; suburban areas, $17.4 \%$; and urban areas, $12.6 \%$. Based on information from The Statistical Abstract of the United States (1982), rural areas were slightly overrepresented in this sample.

3. Most of the LEAs served grades K-12 (88.1\%); $14.1 \%$ served K-6 or K-8; $2.6 \%$ served grades $7-12$ or $9-12$; and $2.2 \%$ served other grade combinations. Many LEAs also reported serving infants or preschool handicapped children.

4. Enrollment patterns for the LEAs included in the study were as follows: Enrollments of: less than $1,000-24.5 \% ; 1,000-4,999-39.3 \%$; $5,000-9,999-14.8 \% ; 10,000-24,999-$ $9.0 \% ; 25,000-50,000-4.6 \%$ and over $50,000-5.8 \%$. When compared to data from the Digest of Education Statistics: 1982 (Grant \& Eiden, 1982), the sample was somewhat underrepresented for small LEAs and overrepresented for large LEAs.

\section{RESULTS}

A total of $89.6 \%$ of the LEAs reported offering a resource room program or its equivalent. Respondents whose LEA did not use this delivery model $(85.7 \%$ of these LEAs had student enrollments of less than 1,000 ) frequently stated that handicapped students were transferred to another LEA. Among LEAs having resource room programs, $59.8 \%$ reportedly initiated the program during the years 1970 through 1975, whereas $9.8 \%$ began prior to 1970. At the other end of the continuum, $26.5 \%$ responded that their programs were started between 1976 and 1980; 3.9\% were implemented in 1981 or 1982.

Of those LEAs using the resource room model, $88.9 \%$ stated that it was called the resource room. An additional $4.2 \%$ used the term resource in some manner (e.g., resource specialist program, extended resource, resource teacher program, consultative resource room). 
Table 1

Description of Sample and Respondents by Region

\begin{tabular}{ccccc}
\hline $\begin{array}{c}\text { Percentage of } \\
\text { National School } \\
\text { Population } \\
(1980)^{\mathbf{a}}\end{array}$ & $\begin{array}{c}\text { Number of } \\
\text { Districts } \\
\text { Contacted }\end{array}$ & $\begin{array}{c}\text { Number of } \\
\text { Returns }\end{array}$ & $\begin{array}{c}\text { Percentage } \\
\text { of Total } \\
\text { (Percentage of } \\
\text { the Sample } \\
\text { for the Region) }\end{array}$ \\
\end{tabular}

Northeast

$5.4 \%$

42

$23(54.8 \%)$

$5.5 \%$

(CT, ME, MA, NH, RI,

VT)

Mid-Atlantic

$15.1 \%$

117

64 (54.7\%)

$15.5 \%$

(NJ, NY, PA)

East North-Central

$19.1 \%$

148

80 (54.1\%)

$19.3 \%$

(IL, IN, MI, OH, WI)

West North-Central

$7.6 \%$

59

30 (50.8\%)

$7.2 \%$

(IA, KS, MO, MN, NE,

ND, SD)

South Atlantic

$16.4 \%$

127

72 (56.7\%)

$17.4 \%$

(DE, FL, GA, MD, NC,

SC, VA, WV)

East South-Central

$6.6 \%$

51

$26(51.0 \%)$

$6.3 \%$

(AL, KY, MS, TN)

West South-Central

$10.9 \%$

85

$38(44.7 \%)$

$9.2 \%$

(AR, LA, OK, TX)

Mountain

$5.5 \%$

43

$26(60.5 \%)$

$6.3 \%$

(AZ, CO, ID, MT, NV,

NM, UT, WY)

Pacific

$13.4 \%$

104

55 (52.9\%)

$13.3 \%$

(AK, CA, OR, WA)

TOTALS

$100.0 \%$

776

$414(53.4 \%)$

$100.0 \%$

$(N=41,316,663)$

Information taken from The Condition of Education (1981). 
The only other term that appeared with some frequency was learning center (2.6\%).

In response to a question about the grade level at which resource room services were available: $58.2 \%$ of the participants stated that the model was available at the kindergarten level; $92.1 \%$ at the elementary level; $90.0 \%$ at the middleschool or junior-high level; and $84.1 \%$ at the high-school level. Of the LEAs serving K-12, $55.1 \%$ offered the resource room as an option at all levels, and $83.2 \%$ provided it as an option in grades $1-12$.

The multicategorical resource room, which pupils from one or several categories of exceptionality may attend at any given time during the day, was reported as an option in $69.1 \%$ of the LEAs. Categorical resource rooms were offered by $36.2 \%$ of the LEAs, whereas itinerant programs (a single resource teacher serving students in more than one building) were available in $26.5 \%$ of the LEAs. A total of $10.1 \%$ of the sample indicated that noncategorical resource rooms (i.e., students receiving services are not identified by exceptionality) were in operation; $2.9 \%$ provided other options. In LEAs offering itinerant programs, teachers served an average of 2.4 buildings, with six being the highest number of buildings served by a single teacher. (The sum of these percentages exceeds 100 since many LEAs utilized more than one type of resource room.)

Table 2 lists the percentage of respondents who stated that the resource room was a service delivery option for various types of students. While the percentages for the mild handicaps were high, only $60.8 \%$ of the LEAs provided the resource room as an alternative for all three categories of exceptionality. Types of student specified in the "other" category included speech and/or language impaired, nonhandicapped, gifted and/or talented, other health impaired, educationally handicapped, and aphasic. Respondents were also asked to indicate the approximate percentage of all handicapped students in their LEAs receiving resource room services; the mean response was $52.9 \%$ with a range from $1 \%(N=4)$ to $100 \%(N=34)$. A total of $27.8 \%$ served more than three-fourths of their handicapped pupils in the resource room; $22.5 \%$ served from $51 \%$ to $75 \%$; $24.1 \%$ served from $26 \%$ to $50 \%$; and $25.6 \%$ served $25 \%$ or fewer.

Just over half of the respondents $(50.3 \%)$ indicated that students could spend up to, but not

Table 2

Types of Students Served in the Resource Room

Type of Student
Percentage of LEAs Using the Resource Room as an Option for Each Category of Exceptionality $(\boldsymbol{N}=\mathbf{3 7 8})$

$\begin{array}{lc}\text { Learning Disabied/SLD } & 98.4 \% \\ \text { Mildly Mentally Handicapped/EMR } & 75.1 \% \\ \text { Emotionally Disturbed/Behavior Disordered } & 69.3 \% \\ \text { Hearing Impaired/Deaf } & 46.3 \% \\ \text { Physically Handicapped } & 45.2 \% \\ \text { Visually Impaired/Blind } & 40.7 \% \\ \text { Moderately Mentally Handicapped/TMR } & 21.7 \% \\ \text { Title I/Chapter I Pupils } & 18.8 \% \\ \text { Other } & 17.5 \%\end{array}$


Table 3

Resource Teacher Caseloads

\begin{tabular}{cccc}
\hline & Mean & $\begin{array}{c}\text { Standard } \\
\text { Deviation }\end{array}$ & $\begin{array}{c}\text { Range } \\
\text { Minimum Caseload } \\
(\mathrm{N}=181)\end{array}$ \\
$\begin{array}{c}\text { Maximum Caseload } \\
(\mathrm{N}=243)\end{array}$ & 11.2 & 6.6 & 0.30 \\
$\begin{array}{c}\text { Average Caseload } \\
(\mathrm{N}=252)\end{array}$ & 25.1 & 9.1 & $4-75$ \\
& 19.4 & 5.6 & $4-40$
\end{tabular}

more than, half the school day in the resource room. An additional $29.8 \%$ reported that the time was not specified, while $19.9 \%$ indicated other time stipulations. In instances where the time was not specified, respondents frequently commented that the time was determined by the IEP team or was based on what seemed appropriate for individual students. For those stating that some other time was specified, responses varied greatly. The most common response $(\mathrm{N}=27)$ was a maximum of two hours or periods per day. A few LEAs had minimum time requirements (e.g., one class period per day). The lowest minimum time allotment was 30 minutes per week compared to a maximum time of $100 \%$ of the school day.

Respondents were asked to specify the minimum, maximum, and average caseload for each resource teacher (i.e., the number of pupils assigned for service). Table 3 lists the means, standard deviations, and range for these variables.

One item of the questionnaire contained 13 activities (plus spaces for other activities) that are often included in lists of resource teacher responsibilities. For each activity, respondents were asked to identify if it was a primary responsibility of resource teachers in the LEA, a secondary responsibility, or not considered a responsibility. Table 4 summarizes the responses in each category for the 13 items. Only 18 respondents listed other responsibilities. These included coordinating the resource program with other programs (e.g., vocational, regular education); selecting special materials; modifying regular classroom handouts, assignments, and textbooks (e.g., by tape recording); and communicating with regular education colleagues about individual students.

Respondents also rated resource room program effectiveness for facilitating students' academic achievement and social skills development. A total of $73.3 \%$ of the sample rated current programs as very effective for increasing academic achievement, with only $4.0 \%$ perceiving them as minimally effective. In terms of social skills development, $50.9 \%$ of the respondents reported that resource programs were very effective, while $10.3 \%$ rated them as being minimally effective.

Only 196 individuals provided information on the approximate per-pupil cost for resource room programs beyond the per-pupil cost for regular education programs. The mean cost was $\$ 1,176.52$ with a standard deviation of $\$ 987.18$. (The range was from zero $(N=8)$ to $\$ 7,000.00 \quad(\mathrm{~N}=1) \quad$ with $53.6 \%$ spending $\$ 1,000.00$ or less and $33.2 \%$ spending from $\$ 1,001.00$ to $\$ 2,000.00$.)

Finally, respondents were asked to indicate 
whether they considered it likely that the resource room program would continue as a major service delivery model in their LEAs over the next 10 years. A total of $84.2 \%$ reported that it was "very likely"; $8.3 \%$ responded that it was "somewhat likely"; whereas $7.5 \%$ considered it "not very likely." The most frequently cited reasons for continuing the resource room program were that it (a) is an effective way to meet students' needs; (b) allows for flexible academic progiam placement in the least restrictive environment; (c) is cost effective; and (d) facilitates the transition of students into regular education placements. Many participants stated that resource room programs would continue as long as funding was available. Those who doubted that the resource model would continue to be used typically listed such reasons as regular education teachers not being receptive to the program or the limited carryover from the resource room to regular education classes.

\section{DISCUSSION}

This study was undertaken to describe present local resource room practices. The results suggest some basic similarities among programs reflecting the recommendations found in the professional literature. At the same time, some discrepancies were noted between recommended practice and actual implementation of this service delivery system.

Most LEAs have resource room programs,

Table 4

Resource Teacher Responsibilities

\begin{tabular}{|c|c|c|c|}
\hline$N=$ Approx. $372^{a}$ & $\begin{array}{c}\text { Percent Stating } \\
\text { the Activity Was } \\
\text { a Primary } \\
\text { Responsibility }\end{array}$ & $\begin{array}{l}\text { Percent Stating } \\
\text { the Activity Was } \\
\text { a Secondary } \\
\text { Responsibility }\end{array}$ & $\begin{array}{c}\text { Percent Stating } \\
\text { the Activity Was } \\
\text { Not a } \\
\text { Responsibility }\end{array}$ \\
\hline Preparing lessons \& materials & $98.4 \%$ & $1.1 \%$ & $.5 \%$ \\
\hline Providing direct instruction & $97.3 \%$ & $1.6 \%$ & $1.1 \%$ \\
\hline Participating in IEP conferences & $94.9 \%$ & $4.3 \%$ & $.8 \%$ \\
\hline Developing IEPs & $91.7 \%$ & $6.7 \%$ & $1.6 \%$ \\
\hline Communicating with parents & $83.4 \%$ & $16.3 \%$ & $.3 \%$ \\
\hline Consulting with school staff & $71.4 \%$ & $27.8 \%$ & $.8 \%$ \\
\hline $\begin{array}{l}\text { Participating in multidisciplinary team } \\
\text { meetings/staffings }\end{array}$ & $71.0 \%$ & $25.5 \%$ & $3.5 \%$ \\
\hline Completing paperwork & $70.8 \%$ & $23.6 \%$ & $5.6 \%$ \\
\hline Assessing students & $57.9 \%$ & $32.4 \%$ & $9.7 \%$ \\
\hline $\begin{array}{l}\text { Observing students in regular education } \\
\text { settings }\end{array}$ & $34.1 \%$ & $44.9 \%$ & $21.0 \%$ \\
\hline Counseling students & $27.4 \%$ & $51.1 \%$ & $21.5 \%$ \\
\hline $\begin{array}{l}\text { Supervising students } \\
\text { (hall duty, lunch duty, etc.) }\end{array}$ & $16.4 \%$ & $48.4 \%$ & $35.2 \%$ \\
\hline $\begin{array}{l}\text { Conducting inservice training for school } \\
\text { personnel }\end{array}$ & $5.9 \%$ & $43.3 \%$ & $50.8 \%$ \\
\hline
\end{tabular}

\footnotetext{
a The number of respondents for each activity varied slightly because some individuals did not respond to all items.
} 
called by the name, most of which have been in existence for at least three years. Elementary and middle/junior-high schools use such programs more frequently than do high schools. The handicapped group served is typically the learning disabled. Although most state guidelines specifically provide for categorical, multicategorical, and itinerant resource rooms (Friend $\&$ McNutt, in press), the majority of LEAs reported using multicategorical programs. This tendency may be indicative of their perception of the financial and administrative expediency of this type of resource room program. Hopefully, it also reflects a recognition of the importance of grouping students by instructional need rather than label. Finally, the infrequent use of noncategorical resource rooms may be attributable to current finding patterns and their impact on state guidelines.

For the most part, information on the cost of operating resource room programs is unavailable. While this, too, may be a result of categorical funding patterns, it is somewhat surprising that LEAs choose not to gather such data. As a result, any large-scale, systematic attempt to examine the cost effectiveness of resource room services is impossible at this time. Given current and future economic constraints, further study in this area seems warranted.

One issue of continuing concern highlighted by this study relates to the responsibilities of resource teachers. While the nearly universal inclusion of such tasks as providing direct instruction, preparing lessons, and completing IEPrelated tasks was expected, the absence of other responsibilities is noteworthy. For example, $50.8 \%$ of the respondents reported that conducting inservice training is not a resource teacher duty. Most authorities in the field, however, have stressed the importance of this resource teacher role for maintaining an effective program (e.g., Elman \& Ginsberg, 1981; Hawisher \& Calhoun, 1978; Wiederholt et al., 1983). Similar statements could be made for counseling students and observing them in regular education settings.

One might conjecture that successful mainstreaming is significantly less likely in LEAs which minimize indirect service roles. However, the question of whether a single individual can adequately carry out all the duties typically assigned to resource teachers must also be raised. One option would be to limit resource teachers' activities to direct instruction and related tasks, leaving indirect services to other school personnel (e.g., counselors, school psychologists). Alternatively, the priority currently given to instructional duties might be lowered to create a more legitimate place for other responsibilities such as inservice training and student observation.

The results of our research indicate that the resource room model is currently the most popular service delivery option in special education. However, the tremendous variation in the way LEAs operate resource room programs leads to a suggestion for future investigation. Since representatives from different LEAs seldom have an opportunity to share ideas on effective practices, it might be beneficial to provide detailed descriptions of exemplary programs. For example, descriptions of successful itinerant or noncategorical programs, or programs in which indirect services constitute an integral component of the resource teacher's job would allow identification of workable strategies. In this way, LEAs would be able to model successful programs while tailoring them to local situations.

\section{REFERENCES}

Elman, N. M., \& Ginsberg, J. N. (1981). The resource room primer. Englewood Cliffs, $\mathrm{NJ}$ : Prentice-Hall.

Friend, M., \& McNutt, G. (in press). Resource room programs: Where are we now? Exceptional Children.

Grant, W. V., \& Eiden, L. S. (1982). Digest of education statistics: 1982. Washington, D.C.: National Center for Education Statistics.

Hawisher, M. F., \& Calhoun, M. 'L. (1978). The resource room. Columbus, $\mathrm{OH}$ : Charles E. Merrill.

Marsh, G. E., Price, B. J., \& Smith, T. E. C. (1983). Teaching mildly handicapped children: Methods and materials. St. Louis: C. V. Mosby.

Mercer, C. D., \& Mercer, A. R. (1981). Teaching students with learning problems. Columbus, $\mathrm{OH}$ : Charles E. Merrill.

Sindelar, P.T., \& Deno, S.L. (1978). The effectiveness of resource programming. Journal of Special Education, 12, 17-28.

U.S. Census Bureau. (1982). Statistical abstract of the United States: 1982-83 (103rd ed.). Washington, D.C.

U.S. Department of Education. (1981). The condition of education (1981 edition). Washington, D.C.: National Center for Education Statistics. 
Wiederholt, J.L., Hammill, D.D., \& Brown, V.L. (1983). The resource teacher: A guide to effective practices(2nd ed.). Austin, TX: PRO-ED.

\section{FOOTNOTES}

This research was partially supported by the University of Oklahoma Research Council.

We wish to thank the personnel who took the time to complete the questionnaires that form the basis of this study, and Regina Blair who did the tedious, time consuming data entry.

Requests for reprints should be addressed to: Gaye McNutt, 9898 Forum Park Dr. ${ }^{*} 6505$, Houston, TX 77036. 